\title{
Analysis of Correlations between the Level of Partnering Relations and their Influence on the Time, Cost, Quality and Safety of Implementation of Construction Projects
}

\author{
Elżbieta Radziszewska-Zielina, Bartłomiej Szewczyk \\ Cracow University of Technology \\ Faculty of Civil Engineering, Department of Construction Technology and Organisation \\ e-mail: eradzisz@izwbit.pk.edu.pl,bszewczyk@izwbit.pk.edu.pl
}

\begin{abstract}
The present paper uses the developed model of the influence of partnering relations on the time, cost, quality and safety of implementation of construction projects. On its basis, a questionnaire has been created and a preliminary survey has been conducted. The paper presents an analysis of correlations between the level of partnering relations in the context of the partnering measures indicated in the model and their influence on the time, cost, quality and safety of implementation of construction projects. The analysis was conducted based on the data collected in 52 construction projects. The values of the Spearman rank correlation coefficient and the Pearson product-moment correlation coefficient have been calculated for the examined relations. The analysis allowed for indicating the measures of partnering whose improvement most often brings benefits with regard to the time, cost, quality and safety of implementation of construction projects. Among the 80 analysed correlations, the ones identified as strong were: 15 relations connected with the time, 8 with the cost, 5 with the quality and 1 with the safety of implementation of construction projects.
\end{abstract}

Key words: construction industry, correlation, partnering relations, survey research

\section{Introduction}

The concept of developing partnering relations between the project participants in the implementation of construction projects have gained in importance in recent years. The concept brings a number of benefits, such as limiting the number of disputes, improving communication between the project participants and reducing the time and cost of the project, as indicated in the publications on the subject, e.g. $[1,2,3]$.

A number of papers about the partnering in construction industry have been written. Some authors have developed conceptual models of partnering, e.g. Cheng and Li [4] and Anvuur and Kumaraswamy [5]. Others have focused on identification of critical success factors of partnering $[6,7,8,9,10]$, such as mutual trust, suitable resources or effective communication. Some publications $[11,12,13]$ are dedicated to the barriers to the application of partnering, 
which is a misunderstanding of the concept of partnering, cultural barriers or uneven involvement of the project participants among others. To maintain partnering relations at the highest possible level and control them, it was necessary to create a system for assessment of partnering relations in construction projects. In recent years, a number of works on this subject have been published [14, 15, 16, 17]. Bayliss et al. present in [14] an example of a method for assessing partnering limited to questionnaire-based evaluation of thirteen measures of partnering by the project participants. On the other hand, [15, 16] present complete assessment methods for partnering relationships in construction projects, including synthetic indicators connecting all studied measures and the computer systems for an improved evaluation process. The authors perform the comparative analysis of five partnering evaluation methods in [18] indicating general characteristics and advantages and disadvantages of each method.

Among few Polish publications on the subject, the author present in [19] a research on partnering relations in construction industry in Poland, Slovakia and Ukraine. The research was carried out using the questionnaire method. 14 parameters of relations and their importance were assessed by: material suppliers, equipment suppliers, subcontractors or main contractors and investors or their representatives. The research indicates that the partnering cooperation among the building contractors in Poland, Slovakia and Ukraine is admittedly noticed but has not reached a high level yet. That research is continued in [20] where assessment methods of partnering in construction enterprises with the use of questionnaires, statistics and fuzzy logic have been presented. Different types of membership functions, methods, defuzzification types and fuzzy action types are examined and the author's own assessment method is selected. It has been developed in [21] the expert control system of partnering relations presented. The author has also developed the method for selecting the best partner construction enterprise in terms of partnering relations [22]. In [23, 24] authors develop a model of partnering relationships' impact on time, cost, quality and safety in construction projects, as shown in Figure 1. Four types of possible partner cooperation in construction projects, according to the cooperation entities, have been identified in that article. Measures of partnering which may influence time, cost, quality and safety of project performance have been indicated.

The aim of the present paper is to investigate correlations between the level of partnering relations in the context of the partnering measures indicated in the model and their influence on the time, cost, quality and safety of implementation of construction projects. It has been assumed that, for projects with a higher level of partnering relations, the influence of these relations on the time, cost, quality or safety is more positive (brings more benefits). Analysis of correlations will allow for indicating those measures of partnering whose improvement most often brings benefits such as reduction of the time and cost of project implementation as well as improvement in their quality and safety.

\section{Research methods}

On the basis of the model of influence of partnering relations on the time, cost, quality and safety of implementation of construction projects, developed in [23] and presented graphically in Figure 1, a questionnaire was prepared which served to investigate the correlation which is the subject of the present study. 


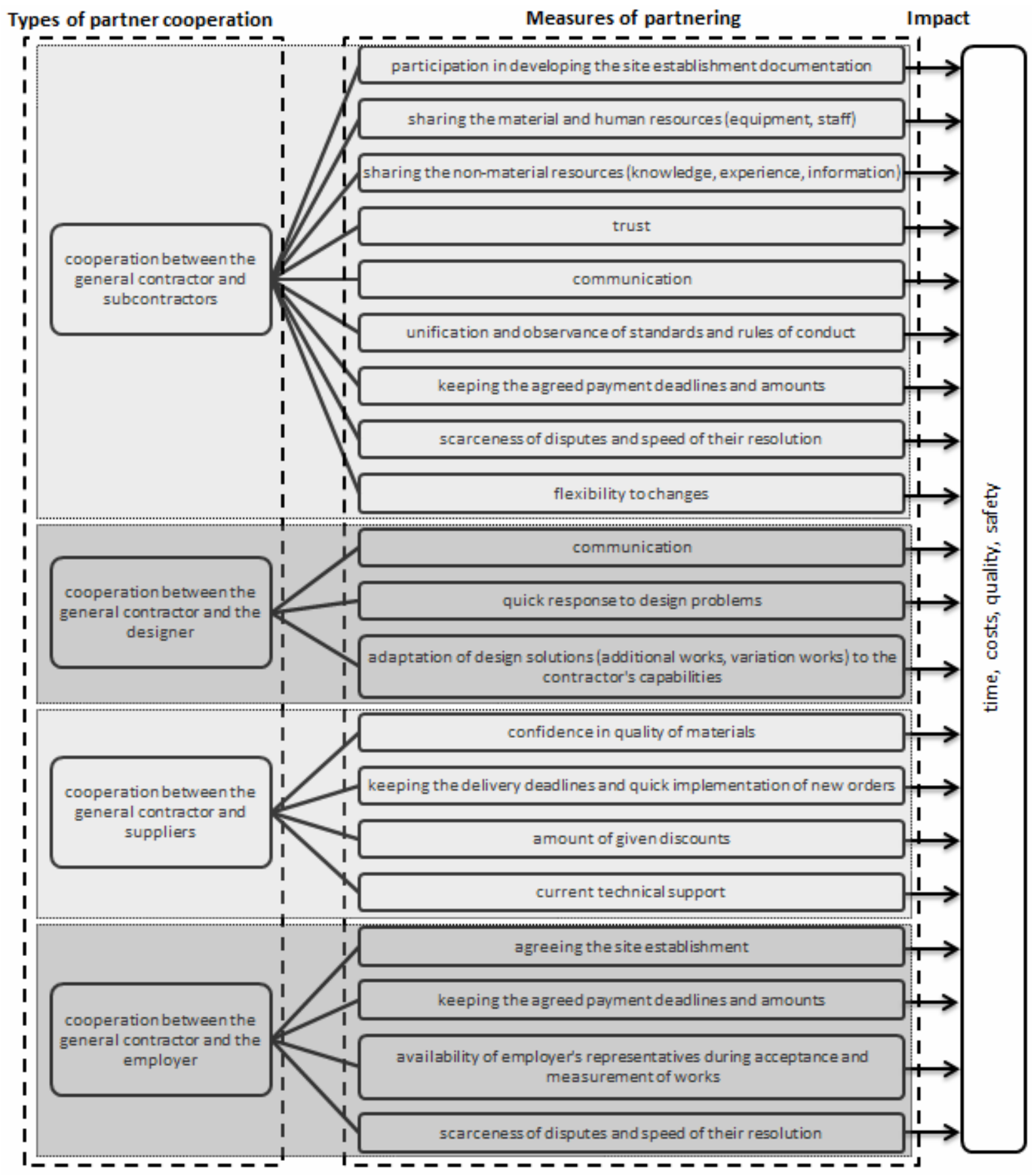

Figure 1: Research model of impact of partnering relations on time, costs, quality and safety in construction projects; source: [23]

In the questionnaire of the survey, in connection with the model developed in [23], four types of partnering relations in construction projects were distinguished with regard to the legal entities with whom the general contractor cooperates: subcontractors, the designer, suppliers, the investor. For each of those types were identified the measures of partnering which may 
have an influence on the time, cost, quality and safety of implementation of construction projects. In the survey, the respondents were first asked for assessment, using the example of a particular construction project, of the level of partnering in the cooperation of the general contractor with a given participant of the construction project in the context of particular measures of partnering. Next, the respondents were asked to assess the influence of those measures on the time, cost, quality and safety of implementation of those construction projects. For the assessment of the level of partnering, a five-degree scale was adopted, consisting of the following grades: very weak, weak, average, good, very good. For the assessment of the influence of partnering on the time, cost, quality and safety of implementation of construction projects, a five-degree scale was adopted, consisting of the following grades: large negative, small negative, no influence, small positive, large positive.

A preliminary survey was conducted for 52 construction projects. The questionnaire was filled in by experts: construction managers who directed construction projects and who had full knowledge of the analysed project. The data collected by means of questionnaires were encoded by ascribing to particular grades the values from 1 to 5 , where 1 is a very weak grade and 5 is very good. Assessment of the influence of the measures of partnering was encoded by ascribing to particular grades the following values: from -2 (for large negative influence) to 2 (for large positive influence). The 0 value corresponds to no influence. For the thus collected data, a correlation analysis was conducted, which was the subject of the present study. Comparison of the obtained results was made using the Spearman rank correlation coefficient (1) and the Pearson product-moment correlation coefficient (2). The former was applied for the ordinal scale of the grades of the level of partnering relations (very weak, weak, average, good, very good) and the ordinal scale of the grades of the influence of the partnering measures (large negative, small negative, no influence, small positive, large positive). The latter was used for the interval scale from 1 to 5 for the grades of the level of partnering relations, and from -2 to 2 for the grades of the influence of the measures of partnering. For both of the correlation coefficients calculated, the significance level $p$ was verified using the tStudent test, assuming that for the significance level lower than or equal 0.05 one must reject the zero hypothesis concerning the lack of dependence between the examined features and assume an alternative hypothesis indicating the occurrence of a relation between them.

$$
\rho=\frac{\left(\frac{n^{3}-n}{12}-T\right)+\left(\frac{n^{3}-n}{12}-U\right)-\sum_{i=1}^{n} d_{i}^{2}}{\sqrt{\left(\frac{n^{3}-n}{12}-T\right) \cdot\left(\frac{n^{3}-n}{12}-U\right)}}
$$

where:

$n$ - the number of ranks,

$d_{i}$ - the difference between the ranks for the examined features,

$T=\frac{1}{12} \sum\left(t_{i}^{3}-t_{i}\right)$ and $U=\frac{1}{12} \sum\left(u_{i}^{3}-u_{i}\right)$, where $t_{i}$ and $u_{i}$ are the number of ranks bounded for the $i$-th value of the $X$ and $Y$ variable. 


$$
r=\frac{\frac{\sum_{i=1}^{n} X_{i} Y_{i}}{n}-\left(\frac{\sum_{i=1}^{n} X_{i}}{n}\right) \cdot\left(\frac{\sum_{i=1}^{n} Y_{i}}{n}\right)}{\sqrt{\frac{\sum_{i=1}^{n} X_{i}^{2}}{n}-\left(\frac{\sum_{i=1}^{n} X_{i}}{n}\right)^{2}} \sqrt{\frac{\sum_{i=1}^{n} Y_{i}^{2}}{n}-\left(\frac{\sum_{i=1}^{n} Y_{i}}{n}\right)^{2}}}
$$

\section{Results}

Table 1 presents the results of the correlation analysis using the Spearman rank correlation coefficient, where the dark fields denote the values of the correlation coefficient whose absolute values are larger than of equal 0.6 , which indicates a high positive correlation (in projects with a higher level of partnering relations, the influence of those relations on time, cost, quality and safety is more positive). Underlined are the values of the significance level above 0.05 , i.e. ones for which one must assume the zero hypothesis concerning the lack of dependence between the examined features.

The values of the Spearman rank correlation coefficient calculated in order to examine the dependence between the level of partnering relations, in the context of the indicated measures of partnering, and their influence on time, cost, quality and safety show that the largest number of strong positive dependences occur for the correlation between the level of partnering relations and the time of construction project implementation (15 out of 20 possible ones). For the level of partnering relations correlated with the cost and quality of construction project implementation, there are respectively 10 and 5 strong positive dependences. The weakest in this respect is the number of correlations between the level of partnering relations and the safety during construction project implementation. The only relation with a strong correlation in this group is the correlation between the level of cooperation with subcontractors in the context of unification and observance of the standards and rules of conduct. The highest value of the Spearman rank correlation coefficient characterises the relation between the level of cooperation with subcontractors in the context of unification and observance of the standards and rules of conduct and the time of construction project implementation (0.764), which suggests that the cooperation in this respect usually means a reduction in the time of project implementation.

The calculated values of the significance level show that for 5 out of the examined correlations one must assume the zero hypothesis concerning the lack of dependence between the examined features. Four of those correlations are connected with the safety and one is connected with the quality of project implementation. Analysis of the table reveals that among the examined parameters the partnering cooperation has the smallest influence on those two above-mentioned ones.

Table 2 presents the results of correlation analysis using the Pearson product-moment correlation coefficient. The values of the correlation coefficient showing a high correlation and the values of the significance level for which the zero hypothesis on the lack of dependence between the examined features must be assumed were marked as in the section above. 
Table 1: Spearman's rank correlation coefficient $\rho$ and statistical significance $p$ for the relationship between the level of partnering relationships in the context of the identified measures of partnering, and their impact on time, cost, quality and safety of construction project performance; source: own work

\begin{tabular}{|c|c|c|c|c|c|c|c|c|c|}
\hline \multirow{3}{*}{ 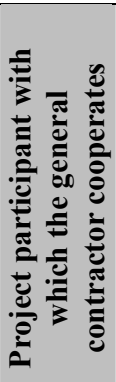 } & \multirow[b]{3}{*}{ Measures of partnering } & \multicolumn{8}{|c|}{ Impact of the measure of partnering on: } \\
\hline & & \multicolumn{2}{|c|}{ Time } & \multicolumn{2}{|c|}{ Cost } & \multicolumn{2}{|c|}{ Quality } & \multicolumn{2}{|c|}{ Safety } \\
\hline & & 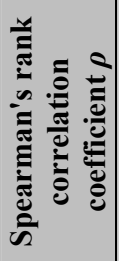 & 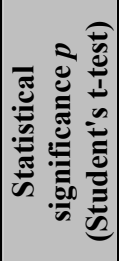 & 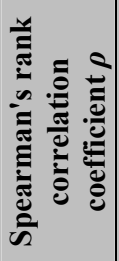 & 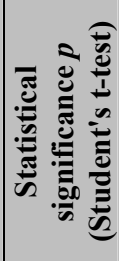 & 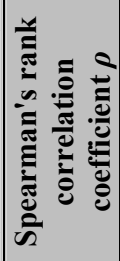 & 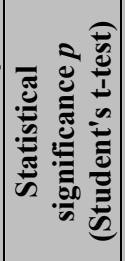 & 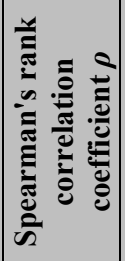 & 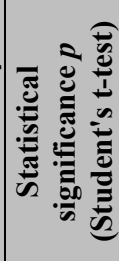 \\
\hline \multirow{9}{*}{ 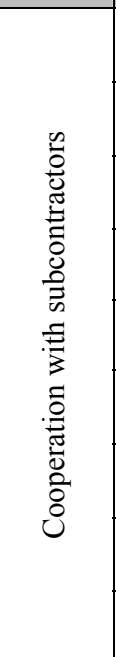 } & $\begin{array}{l}\text { participation in developing the site } \\
\text { establishment documentation }\end{array}$ & 0.587 & 0.000 & 0.536 & 0.000 & 0.342 & 0.013 & 0.523 & 0.000 \\
\hline & $\begin{array}{l}\text { sharing the material and human } \\
\text { resources (equipment, staff) }\end{array}$ & 0.564 & 0.000 & 0.603 & 0.000 & 0.378 & 0.006 & 0.343 & 0.014 \\
\hline & $\begin{array}{l}\text { sharing the non-material resources } \\
\text { (knowledge, experience, information) }\end{array}$ & 0.726 & 0.000 & 0.529 & 0.000 & 0.597 & 0.000 & 0.448 & 0.001 \\
\hline & trust & 0.612 & 0.000 & 0.546 & 0.000 & 0.319 & 0.021 & 0.483 & 0.000 \\
\hline & communication & 0.662 & 0.000 & 0.615 & 0.000 & 0.557 & 0.000 & 0.444 & 0.001 \\
\hline & $\begin{array}{l}\text { unification and observance of } \\
\text { standards and rules of conduct }\end{array}$ & 0.764 & 0.000 & 0.663 & 0.000 & 0.692 & 0.000 & 0.694 & 0.000 \\
\hline & $\begin{array}{l}\text { keeping the agreed payment deadlines } \\
\text { and amounts }\end{array}$ & 0.684 & 0.000 & 0.694 & 0.000 & 0.618 & 0.000 & 0.418 & 0.002 \\
\hline & $\begin{array}{c}\text { scarceness of disputes and speed of } \\
\text { their resolution }\end{array}$ & 0.643 & 0.000 & 0.587 & 0.000 & 0.408 & 0.003 & 0.283 & 0.042 \\
\hline & flexibility to changes & 0.740 & 0.000 & 0.631 & 0.000 & 0.447 & 0.001 & 0.193 & $\underline{0.170}$ \\
\hline \multirow{3}{*}{ 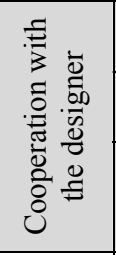 } & communication & 0.747 & 0.000 & 0.687 & 0.000 & 0.530 & 0.000 & 0.217 & $\underline{0.123}$ \\
\hline & quick response to design problems & 0.709 & 0.000 & 0.719 & 0.000 & 0.650 & 0.000 & 0.341 & 0.013 \\
\hline & $\begin{array}{l}\text { adaptation of design solutions } \\
\text { (additional works, variation works) to } \\
\text { the contractor's capabilities }\end{array}$ & 0.672 & 0.000 & 0.733 & 0.000 & 0.458 & 0.001 & 0.405 & 0.003 \\
\hline \multirow{4}{*}{ 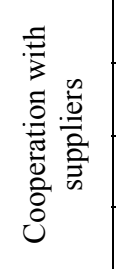 } & confidence in quality of materials & 0.416 & 0.002 & 0.489 & 0.000 & 0.570 & 0.000 & 0.216 & $\underline{0.125}$ \\
\hline & $\begin{array}{l}\text { keeping the delivery deadlines and } \\
\text { quick implementation of new orders }\end{array}$ & 0.536 & 0.000 & 0.346 & 0.012 & 0.066 & $\underline{0.640}$ & 0.000 & $\underline{0.998}$ \\
\hline & amount of given discounts & 0.379 & 0.006 & 0.564 & 0.000 & 0.533 & 0.000 & 0.274 & 0.050 \\
\hline & current technical support & 0.731 & 0.000 & 0.521 & 0.000 & 0.625 & 0.000 & 0.293 & 0.035 \\
\hline \multirow{4}{*}{ 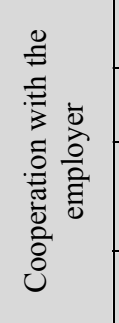 } & agreeing the site establishment & 0.643 & 0.000 & 0.668 & 0.000 & 0.443 & 0.001 & 0.476 & 0.000 \\
\hline & $\begin{array}{l}\text { keeping the agreed payment deadlines } \\
\text { and amounts }\end{array}$ & 0.648 & 0.000 & 0.555 & 0.000 & 0.512 & 0.000 & 0.334 & 0.015 \\
\hline & $\begin{array}{l}\text { availability of employer's } \\
\text { representatives during acceptance and } \\
\text { measurement of works }\end{array}$ & 0.730 & 0.000 & 0.453 & 0.001 & 0.624 & 0.000 & 0.395 & 0.004 \\
\hline & $\begin{array}{c}\text { scarceness of disputes and speed of } \\
\text { their resolution }\end{array}$ & 0.630 & 0.000 & 0.666 & 0.000 & 0.530 & 0.000 & 0.326 & 0.018 \\
\hline
\end{tabular}


Table 2: Pearson product-moment correlation coefficient $r$ and statistical significance $p$ for the relationship between the level of partnering relationships in the context of the identified measures of partnering, and their impact on time, cost, quality and safety of construction project performance; source: own work

\begin{tabular}{|c|c|c|c|c|c|c|c|c|c|}
\hline \multirow{3}{*}{ 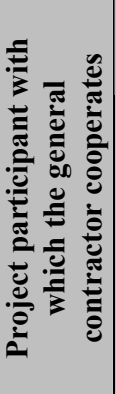 } & \multirow[b]{3}{*}{ Measure of partnering } & \multicolumn{8}{|c|}{ Impact of the measure of partnering on: } \\
\hline & & \multicolumn{2}{|c|}{ Time } & \multicolumn{2}{|c|}{ Cost } & \multicolumn{2}{|c|}{ Quality } & \multicolumn{2}{|c|}{ Safety } \\
\hline & & 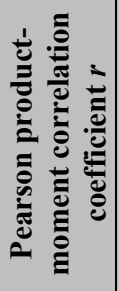 & 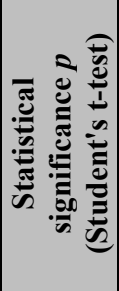 & 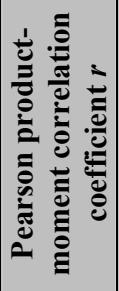 & 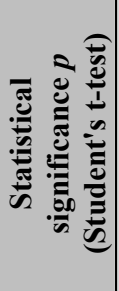 & 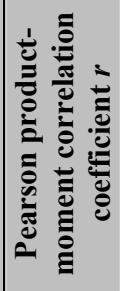 & 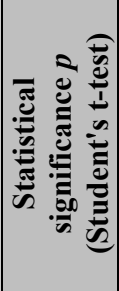 & 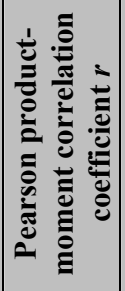 & 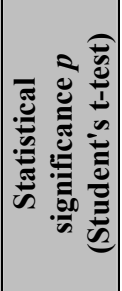 \\
\hline \multirow{9}{*}{ 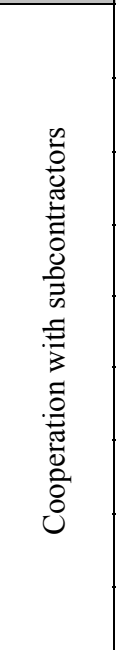 } & $\begin{array}{l}\text { participation in developing the site } \\
\text { establishment documentation }\end{array}$ & 0.567 & 0.000 & 0.524 & 0.000 & 0.368 & 0.007 & 0.536 & 0.000 \\
\hline & $\begin{array}{l}\text { sharing the material and human } \\
\text { resources (equipment, staff) }\end{array}$ & 0.512 & 0.000 & 0.538 & 0.000 & 0.369 & 0.008 & 0.331 & 0.018 \\
\hline & $\begin{array}{l}\text { sharing the non-material resources } \\
\text { (knowledge, experience, information) }\end{array}$ & 0.684 & 0.000 & 0.555 & 0.000 & 0.609 & 0.000 & 0.462 & 0.001 \\
\hline & trust & 0.617 & 0.000 & 0.544 & 0.000 & 0.329 & 0.017 & 0.477 & 0.000 \\
\hline & communication & 0.690 & 0.000 & 0.632 & 0.000 & 0.578 & 0.000 & 0.474 & 0.000 \\
\hline & $\begin{array}{l}\text { unification and observance of } \\
\text { standards and rules of conduct }\end{array}$ & 0.718 & 0.000 & 0.590 & 0.000 & 0.649 & 0.000 & 0.695 & 0.000 \\
\hline & $\begin{array}{l}\text { keeping the agreed payment deadlines } \\
\text { and amounts }\end{array}$ & 0.694 & 0.000 & 0.702 & 0.000 & 0.631 & 0.000 & 0.479 & 0.000 \\
\hline & $\begin{array}{c}\text { scarceness of disputes and speed of } \\
\text { their resolution }\end{array}$ & 0.614 & 0.000 & 0.604 & 0.000 & 0.424 & 0.002 & 0.292 & 0.036 \\
\hline & flexibility to changes & 0.694 & 0.000 & 0.657 & 0.000 & 0.471 & 0.000 & 0.196 & $\underline{0.163}$ \\
\hline \multirow{3}{*}{ 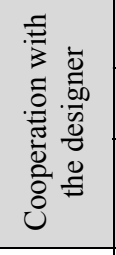 } & communication & 0.752 & 0.000 & 0.694 & 0.000 & 0.543 & 0.000 & 0.211 & $\underline{0.133}$ \\
\hline & quick response to design problems & 0.708 & 0.000 & 0.715 & 0.000 & 0.601 & 0.000 & 0.334 & 0.015 \\
\hline & $\begin{array}{c}\text { adaptation of design solutions } \\
\text { (additional works, variation works) to } \\
\text { the contractor's capabilities }\end{array}$ & 0.672 & 0.000 & 0.722 & 0.000 & 0.456 & 0.001 & 0.417 & 0.002 \\
\hline \multirow{4}{*}{ 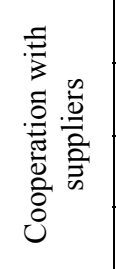 } & confidence in quality of materials & 0.557 & 0.000 & 0.587 & 0.000 & 0.664 & 0.000 & 0.334 & 0.016 \\
\hline & $\begin{array}{l}\text { keeping the delivery deadlines and } \\
\text { quick implementation of new orders }\end{array}$ & 0.529 & 0.000 & 0.387 & 0.005 & 0.093 & $\underline{0.510}$ & -0.019 & $\underline{0.896}$ \\
\hline & amount of given discounts & 0.396 & 0.004 & 0.609 & 0.000 & 0.554 & 0.000 & 0.277 & 0.047 \\
\hline & current technical support & 0.697 & 0.000 & 0.506 & 0.000 & 0.603 & 0.000 & 0.283 & 0.042 \\
\hline \multirow{4}{*}{ 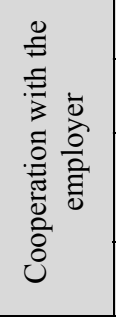 } & agreeing the site establishment & 0.672 & 0.000 & 0.702 & 0.000 & 0.514 & 0.000 & 0.579 & 0.000 \\
\hline & $\begin{array}{l}\text { keeping the agreed payment deadlines } \\
\text { and amounts }\end{array}$ & 0.710 & 0.000 & 0.681 & 0.000 & 0.571 & 0.000 & 0.387 & 0.005 \\
\hline & $\begin{array}{c}\text { availability of employer's } \\
\text { representatives during acceptance and } \\
\text { measurement of works }\end{array}$ & 0.823 & 0.000 & 0.625 & 0.000 & 0.729 & 0.000 & 0.522 & 0.000 \\
\hline & $\begin{array}{l}\text { scarceness of disputes and speed of } \\
\text { their resolution }\end{array}$ & 0.645 & 0.000 & 0.664 & 0.000 & 0.556 & 0.000 & 0.341 & 0.013 \\
\hline
\end{tabular}


The calculated values of the Pearson product-moment correlation coefficient indicate the occurrence of strong positive dependences in the same correlations, related to the time and safety of implementation, as in the case of the Spearman rank correlation coefficient. For the level of partnering relations correlated with the cost and quality of construction project implementation, there are respectively 12 and 7 strong positive dependences. The highest value of the Pearson product-moment correlation coefficient characterises the relation between the level of cooperation with the investor in the context of availability of the employer's representatives during acceptance and measurement of works and the time of construction project implementation by the development of partnering relations in this respect.

Four out of the calculated values of the significance level for the examined correlations indicate that one must assume the zero hypothesis on the lack of dependence between the examined features. Three of those correlations are connected with the safety and one is connected with the quality of construction project implementation.

The correlations identified as strong by both of the correlation coefficients overlap to a large extent. The Spearman rank correlation coefficient identifies as strong 31 out of 80 examined correlations whereas the Pearson product-moment correlation coefficient identifies 35 . The correlations identified as strong by the above correlation coefficients are the same in 29 cases.

\section{Conclusion}

The paper presented an analysis of correlations between the level of partnering relations in the context of the indicated measures of partnering and their influence on the time, cost, quality and safety of construction project implementation. The analysis confirms the previous results of research on the benefits of partnering [1, 2, 3]. Moreover, by identifying strong correlations, it indicates those measures of partnering which bring the most benefits with regard to the time, cost, quality and safety of construction project implementation. Table 3 presents those measures of partnering for which the examined correlations were described as strong by both of the correlation coefficients applied.

On the basis of the occurrence of the positive correlation it may be stated that, for projects with a higher level of partnering relations, the influence of those relations on the time, cost, quality and safety is more positive (brings larger benefits). Analysis of the strong correlations in Table 3 shows that all of the examined measures of partnering concerning cooperation with the designer and the investor are strongly connected with the time of construction project implementation. Therefore it may be concluded that their improvement shortens the time of construction project implementation. In the case of cooperation with the designer, all of the analysed measures of partnering are also strongly connected with the cost of construction project implementation. Moreover, partnering cooperation in the context of the speed of response to design problems also brings quality improvement. Among the measures related to cooperation with suppliers only the current technical support may be indicated as bringing benefits both with respect to the time and the quality of project implementation. The analysis shows that the development of partnering relations in cooperation with the investor brings benefits also with regard to the cost and quality of project implementation. 
Table 3: Strong correlation between the level of partnering relationships in the context of the identified measures of partnering, and their impact on time, cost, quality and safety of construction project performance; source: own work

\begin{tabular}{|c|c|c|c|c|c|}
\hline \multirow{2}{*}{ 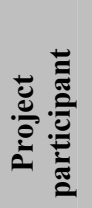 } & \multirow[b]{2}{*}{ Measure of partnering } & \multicolumn{4}{|c|}{ Impact of the measure of partnering on: } \\
\hline & & Time & Cost & Quality & Safety \\
\hline \multirow{9}{*}{ 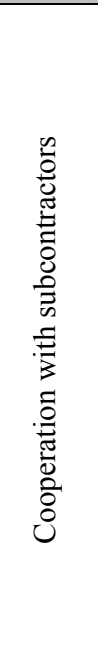 } & $\begin{array}{c}\text { participation in developing the site } \\
\text { establishment documentation }\end{array}$ & & & & \\
\hline & $\begin{array}{l}\text { sharing the material and human resources } \\
\text { (equipment, staff) }\end{array}$ & & & & \\
\hline & $\begin{array}{c}\text { sharing the non-material resources } \\
\text { (knowledge, experience, information) }\end{array}$ & $\mathrm{X}$ & & & \\
\hline & trust & $\mathrm{X}$ & & & \\
\hline & communication & $\mathrm{X}$ & $\mathrm{X}$ & & \\
\hline & $\begin{array}{l}\text { unification and observance of standards and } \\
\text { rules of conduct }\end{array}$ & $\mathrm{X}$ & & $\mathrm{X}$ & $\mathrm{X}$ \\
\hline & $\begin{array}{l}\text { keeping the agreed payment deadlines and } \\
\text { amounts }\end{array}$ & $\mathrm{X}$ & $X$ & $\mathrm{X}$ & \\
\hline & $\begin{array}{l}\text { scarceness of disputes and speed of their } \\
\text { resolution }\end{array}$ & $\mathrm{X}$ & & & \\
\hline & flexibility to changes & $\mathrm{X}$ & $\mathrm{X}$ & & \\
\hline \multirow{3}{*}{ 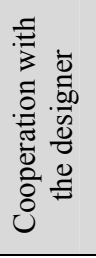 } & communication & $\mathrm{X}$ & $X$ & & \\
\hline & quick response to design problems & $\mathrm{X}$ & $\mathrm{X}$ & $\mathrm{X}$ & \\
\hline & $\begin{array}{l}\text { adaptation of design solutions (additional } \\
\text { works, variation works) to the contractor's } \\
\text { capabilities }\end{array}$ & $\mathrm{X}$ & $\mathrm{X}$ & & \\
\hline \multirow{4}{*}{ 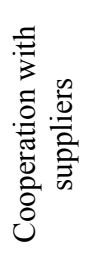 } & confidence in quality of materials & & & & \\
\hline & $\begin{array}{l}\text { keeping the delivery deadlines and quick } \\
\text { implementation of new orders }\end{array}$ & & & & \\
\hline & amount of given discounts & & & & \\
\hline & current technical support & $\mathrm{X}$ & & $\mathrm{X}$ & \\
\hline \multirow{4}{*}{ 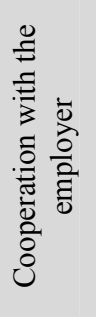 } & agreeing the site establishment & $\mathrm{X}$ & $\mathrm{X}$ & & \\
\hline & $\begin{array}{l}\text { keeping the agreed payment deadlines and } \\
\text { amounts }\end{array}$ & $\mathrm{X}$ & & & \\
\hline & $\begin{array}{c}\text { availability of employer's representatives } \\
\text { during acceptance and measurement of } \\
\text { works }\end{array}$ & $X$ & & $\mathrm{X}$ & \\
\hline & $\begin{array}{l}\text { scarceness of disputes and speed of their } \\
\text { resolution }\end{array}$ & $\mathrm{X}$ & $\mathrm{X}$ & & \\
\hline
\end{tabular}

The calculated values of the Pearson product-moment correlation coefficient indicate the occurrence of strong positive dependences in the same correlations, related to the time and safety of implementation, as in the case of the Spearman rank correlation coefficient. For the 
level of partnering relations correlated with the cost and quality of construction project implementation, there are respectively 12 and 7 strong positive dependences. The highest value of the Pearson product-moment correlation coefficient characterises the relation between the level of cooperation with the investor in the context of availability of the employer's representatives during acceptance and measurement of works and the time of construction project implementation by the development of partnering relations in this respect.

The partnering cooperation with subcontractors brings benefits in the aspects of the time, cost, quality and safety of project implementation. This leads to a conclusion that companies which want to improve time or cost performance, quality or safety in theirs projects ought to focus on those measures of partnering that are strongly correlated with each parameter.

The analysis also allows for the statement that, out of the 4 examined parameters, partnering relations have the largest influence on the time of project implementation, the smallest influence on the safety and an indirect influence on the cost and quality of project implementation. These points to the advisability of focusing in further analyses on the time, cost and quality as the features related to partnering relations, and a possibility to disregard the influence on the safety, being weakly connected with partnering relations. In further publications, the measures of partnering presented in Table 3 will be used to create a system of assessment and control of partnering relations in construction projects.

\section{References}

[1] Black, C., Akintoyeb, A., Fitzgerald, E. (2000). An analysis of success factors and benefits of partnering in construction, International Journal of Project Management, 18, pp. 423-434.

[2] Chan, A.P.C., Chan, D.W.M., Ho, K.S.K. (2003). An empirical study of the benefits of construction partnering in Hong Kong, Construction Management and Economics, 21, pp. 523533.

[3] Beach, R., Webster, M., Campbell, K.M. (2005). An evaluation of partnership development in the construction industry, International Journal of Project Management, 23(8), pp. 611-21.

[4] Cheng, E. W. L., Li, H. (2001). Development of a conceptual model of construction partnering, Engineering, Construction and Architectural Management, 8(4), pp. 292-303.

[5] Anvuur, A.M., Kumaraswamy, M. M. (2007). Conceptual model of partnering and alliancing, Journal of Construction Engineering and Management, 133(3), pp. 225-234.

[6] Cheng, E. W. L., and Li, H. (2002). Construction partnering process and associated critical success factors: quantitative investigation, Journal of Management in Engineering, 18(4), pp. 194-202.

[7] Chan, A., Chan, D., Chiang, Y., Tang, B., Chan, E., Ho, K. (2004). Exploring critical success factors for partnering in construction projects, Journal of Construction Engineering and Management, 130(2), pp. 188-198.

[8] Cheng, E., Li, H., Love, P. (2000). Establishment of critical success factors for construction partnering, Journal of Management in Engineering, 16(2), pp. 84-92

[9] Kozlovská, M., Struková, Z. (2013) Integration of Occupational Safety to Contractors`or Subcontractors' Performance Evaluation in Construction Projects. SSP - Journal of civil engineering : Selected scientific papers, 8 (1), pp. 13-24. 
[10] Mesároš, P., Mandičák, T., Mesárošová, M. (2014). Competency-based management of information flows in construction projects. In: SGEM 2014 : 14th international multidiscilinary scientific geoconference : GeoConference on Informatics, Geoinformatics and Remote Sensing : conference proceedings : volume 1 : 17-26, June, 2014, Albena, Bulgaria. - Sofia : STEF92 Technology Ltd., 2014 P. 89-96. ISBN 978-619-7105-10-0

[11] Mandičák, T., Mesároš, P., Selín, J. (2013). Information system as a tool for cost management in Slovak construction enterprises. In: Ekonomika a manažment podniku. Roč. 11, č. 1-2 (2013), s. 5-16. ISSN 1336-4103

[12] Eriksson, P. E., Nilsson, T. (2008). Client perceptions of barriers to partnering. Engineering, Construction and Architectural Management, 15(6), pp. 527-539.

[13] Chan, A. P. C., Chan, D. W. M., and Ho, K. S. K. (2003). Partnering in construction: Critical study of problems for implementation. Journal of Management in Engineering, 19(3), pp. 126135.

[14] Bayliss R., Cheung S.O., Suen H.C.H., Wong S.P. (2004). Effective partnering tools in construction: a case study on MTRC TKE contract 604 in Hong Kong. International Journal of Project Management, 22, pp. 253-263.

[15] Cheung S.O., Suen H.C.H., Cheung K.K.W. (2003). An automated partnering monitoring system - Partnering Temperature Index. Automation in Construction, 12, pp. 331- 345.

[16] Yeung J.F.Y., Chan A.P.C., Chan D.W.M. (2009). A computerized model for measuring and benchmarking the partnering performance of construction projects. Automation in Construction, 18, pp. 1099-1113.

[17] Kozlovská, M., Struková, Z. (2012) Overview of Safety Risk Perception in Construction. Journal of Civil Engineering and Architecture, 6 (2), p. 211-218.

[18] Radziszewska-Zielina E., Szewczyk B. (2014). Analysis of methods for assessing partner relationships in construction projects. Technical Transactions, 2-B/2014, pp. 49-56

[19] Radziszewska-Zielina E. (2010). Analysis of the partnering relations of Polish, Slovak and Ukrainian construction enterprises. Technological and Economic Development of Economy, 16(3), pp.432-454.

[20] Radziszewska-Zielina E. (2011). Assessment methods of partnering relations of Polish, Slovak and Ukrainian construction enterprises with the fuzzy logic. Archives of Civil Engineering, 57(1), pp.87-118.

[21] Radziszewska-Zielina E. (2011). Fuzzy control of the partnering relations of a construction enterprise. Journal of Civil Engineering and Management, 17(1), pp. 5-15

[22] Radziszewska-Zielina E. (2010). Methods for selecting the best partner construction enterprise in terms of partnering relations. Journal of Civil Engineering and Management, 16(4), pp. 510520.

[23] Radziszewska-Zielina E., Szewczyk B. (2014). The model of partner relationships' impact on time, cost, quality and safety in construction projects. In International Scientific Conference People, Buildings and Environment, 15-17.10.2014. Brno University of Technology, Faculty of Civil Engineering

[24] Kozlovská M., Tažiková A., Purcz P. (2011). Model for early valuation of construction time. SSP-Journal of civil engineering, 6(1), p. 53-64. 